UDC 378.147:52:38.094(430+477)2

\title{
COMPARATIVE CHARACTERISTICS OF TEACHING MATHEMATICS IN COLLEGES AND GYMNASIUMS IN GERMANY AND UKRAINE
}

\author{
Elina Zhelezniakova \\ Candidate of Physic-Mathematical Sciences, \\ Associate Professor of High Mathematic and Mathematical Methods \\ in Economic Department \\ Simon Kuznets Kharkiv National University of Economics \\ Kharkiv, Ukraine \\ ORCID ID 0000-0001-6409-4761 \\ Zheleznizkova@m.hneu.edu.ua \\ Tetiana Silichova \\ Candidate of Pedagogical Sciences, \\ Associate Professor of High Mathematic and Mathematical Methods \\ in Economic Department \\ Simon Kuznets Kharkiv National University of Economics \\ Kharkiv, Ukraine \\ ORCID ID 0000-0001-5003-2711 \\ tas.20.05.72@gmail.com
}

\begin{abstract}
The article describes the main features, aspects and issues that can be problem for domestic applicants when they like to study at higher education institutions in Germany. The relevance of the issue under the study is proved by the fact that the global market of modern education is one of the most rapidly developing areas of the economy. In some countries, the profit from the export of educational services is so great, that it is one of the main sources of income for these countries. The number of students studying abroad is constantly growing. The main attention in the paper is paid to the fact that in addition to difficulties of psycho-social nature, a new style of life and new surrounding, the young people can encounter more serious difficulties: a mismatch in the level of professional training.

The authors emphasize on the necessity to pay attention to the difference between the systems of school education in Ukraine and Germany. So they say that in Ukraine every student must have a complete school education to enter a higher education institution. If applicant graduates from a technical school (college), then he/ she has possibility to enter the second or the third year of studying at the corresponding University. In German the situation is different, its analysis is presented in the paper. There are noted not only main differences in education system as whole, but in the methods of teaching certain courses on example of teaching mathematics. The main focuses are made on the themes that are highlighted in the last school years, and themes of entrance exams at German universities. The analysis allows the authors to argue that preparing for further studying abroad is a complex process, requiring a difficult professional and educational training.
\end{abstract}

Key words: higher education institution; mathematics; education; adaptation problem; professional training; exam. 
Introduction. The global market of modern education is one of the most rapidly developing areas of the economy. In some countries, the profit from the export of educational services is so great, that it is one of the main sources of income for these countries. The number of students studying abroad is constantly growing. Of course, the leader in providing educational services is United States of America, but due the lack of real free educational programs, higher education in the USA is not available to most Ukrainian applicants.

European countries that offer free opportunities to study are especially popular among Ukrainians. They are Poland, Czech Republic, Germany, Austria, and France. The fact that in the most of these countries an entrance exam for studying is not required makes the possibility to go to the universities so interesting and attractive too.

Of course, it is so profitably to have foreign students for any university, because, firstly, it is a good involvement of additional funds into the country's economy (even with free tuition, students must pay for accommodation, meals, buy literature, etc.), but also as statistic shows, most of them stay in the countries of study and don't come back. For example, more than $80 \%$ of foreigners who study at US universities never come back and stay to work for the good of America (Topchii, 2011; Demidov, 2011; Dergai, 2011; Shkliar, 2011). In addition, a fact that a lot of students from a different countries study at the university helps to increase its popularization among a big number of higher education institutions in the world. The main problems for future students are that this free education is available only under the condition to study in the country's language, and the most universities demand to have good, sometimes excellent marks in a school certificate or a list of good (excellent) grades per semester and high level of a language exam at level B1-C1. These requirements depend on the university and the future profession (Matsko, 2019).

But the situation is not so easy for an applicant as somebody can imagine. For example, the future student has passed the necessary language exam, has necessary marks on the grades list. What is expecting him/her next? It should be noted that in addition to psychological discomfort, getting through a new social conditions, a new educational environment and language barrier, there is another very important difficulty: the level of compliance of Ukrainian school education is not equal to the level of school education of the foreign country. And very often these two levels are not corresponding to each other completely.

Analysis of publications. A lot of scientists are studying the issue of adaptation of domestic students in the new educational environments. So, O. Matsko pays her attention to the complexity of students' adaptation and associates this precisely with the difficulties in language. Her research shows that preference is given to the countries

Професіоналізм педагога: теоретичні й методичні аспекти. - Вип. 12. - Слов'янськ, 2020. 
where the language is close enough to the native language of persons (for example, Russia or Poland, if we talk about Ukrainian students). A. Vakhstein, A Bozhenkova, and O. Perfilieva, who study and compare the educational systems of Russia, Norway, and Canada, believe that the foundation for further successful education is the foundation that is established in the school, and with this statement we can't disagree, and it will be further discussed in this article. The fact of the success of future specialist as result of realization of the continuous education structure can be seen in the works of B. Zheleznov, T. Meshkov, E. Horbunova, and M. Larioniva. It should be noted that the education system in Germany, which is presented by the structure "primary school, secondary school, gymnasium and university", completely implements this scenario.

According to what has been said above, it should be noted that the difference between the mathematical training has not been studied enough till now. There are separate studies about the comparison of mathematical training in the USA (works by M. Borg, V. Grail, and others), among the domestic scientists it is necessary to pay attention to the works of Y. Huletska and V. Dikan. Considering that the mathematics is one of the main and fundamental courses that opens the door to the future entrance to the university, this article studies in details the problems and difficulties of mathematical training that the future student may encounter while studying at German university.

Purpose of this article is to compare main characteristics of the mathematical training of future applicants in Germany and Ukraine.

Results. Firstly, it is necessary to pay attention to the difference between the systems of school education in two countries. So, in Ukraine, every child must have a full school education to enter a higher education institution. If applicant graduates from a technical school (college), then he/ she has possibility to enter the second or the third year of studying at the corresponding University.

In Germany the system of colleges (technical schools) doesn't exists in this ordinary way. The German school system has a difficult structure and is divided into three main parts (shortened view): primary school (Grundschule), professional school (Realschule, Hauptschule, Gesamtschule, Sekundarschule) and gymnasium (Gymnasium) as a special part of secondary school. Every child must visit elementary school (Grundschule). After certain years of study (it is usually between four and six years) the ways of pupils are different. Some of them go to professional schools (Realschule, Hauptschule, Gesamtschule, Sekundarschule, etc.), others go to gymnasium (Gymnasium).

Thus, the system of colleges, lyceums and professional schools that exists in Ukraine is not the same as in Germany in comparable way. And the children, who have 
such level of basic secondary school (just like Hauptschule, Realschule, Gesamtschule, Sekundarschule, etc.), have mostly lower level of their educational training in comparison with the students of gymnasium. Most time of studying in Gesamtschule, Realschule, and Hauptschule prepares usually for upcoming vocational training in a future job and contains basic qualifications in the typical subjects.

However, the pupils, who choose the gymnasium as the stage of their further education, on the contrary, receive more intensive level of theoretical training, because the main goal of their learning process is passing Abitur exam, which is, on the one hand, the evidence of successful gymnasium graduation and, on the other hand, it is an entrance to the university. It should be noted that such a system of education is far from perfect, and criticized in German.

Firstly, the age when a child must choose between Gesamtschule, Sekundarschule, Berufsschule, Realschule, Hauptschule or Gymnasium is between 10 and 12 that depends on the "Bundesland" and so often the decision is made by parents. Secondly, only to have a wish to enter the gymnasium is not enough, the future students usually must have good marks, a recommendation from the primary school, and in some cases must successfully pass an entrance exam. In fact, it can happen that young people, who, for example, have worked for five years as regular worker (after school degree), wants to get university education. But as result of the initially lower level of preparation at basic secondary school, they cannot pass Abitur exam. In order to fulfill students' plans, they must either study additionally themselves or attend one of the many different opportunities just like adult schools (Abendschule, Volkshochschule, etc.) to fulfill the gaps in the evenings. It is quite difficult and time-consuming, and only motivated persons take this way. The main part of students at German universities are yesterday's gymnasium students who have passed Abitur exam and are ready for it while studying in forms 11-13.

Also, it should be noted that the education system isn't completely equal in Germany, there is some difference between schools but it depends from German states ("Bundeslände"). So, for example, in some states a gymnasium has 12-year education, others have 13-year ones.

Somebody believes that the education in foreign schools is quite easy, much easier and simpler than in Ukrainian schools. This is really so, if we talk about the first two levels of training. But the math course in gymnasium is almost equial to the first math course at Ukrainian universities at non-mathematical faculties. And for further successful and painless adaptation in the educational environment of Germany, it is necessary to be prepared for this. Let's show some examples, for instance, the topic 
"The course of fractional rational functions". ("Kurse für Kurvendiskussion gebrochen-rationaler Funktionen").

This course not only explains such kind of function, their types, constructions, graphs, but also offers a complete study with using various methods of differential calculus: the points of minimum and maximum, intervals of increasing and decreasing, the behavior of the function at infinity and at break points (left and right limits), it is made an analysis of the existence of three types of asymptotes (vertical, horizontal and inclined). Students know about existence the intervals of concavity and convexity and inflection points, they are able to discover the points of removable discontinuity and are able to redefine the function at these points.

While studying math, the special attention should be paid to existence of significant differences in some definitions and concepts. So, for example, in the theme "Researching and Building the Functions Graphs" the definition of points where the function is zero (zero function: $f(x)=0$ ) is Nullstelle, but there is no any real definition of "argument zeros", points where $x=0$. In this case the question of such kind task is looking something like this: "Find the coordinates of the points where the function intersects the Y-axis"'.

In other way, if we want to solve some of examples, we can meet fairly often the notions of a denominator zeros and a numerator zero, which are also called Nullstelle. For example, if we speak separately about a numerator and denominator, then for function

$$
f(x)=\frac{(x+3)(x+1)}{(x-2)(x-3)} \text {, the points } x=2, x=3 \text { are the zeros of denominator }
$$

(Nullstellen des Nenners), and $x=-3, x=-1$ are the zeros of numerator (Nullstellen des Zählers).

But, for example, if the condition of our exercise is changed, it looks like this: "Find the domain of function (Definitiosnbereich) $f(x)=\frac{(x+3)(x+1)}{(x-2)(x-3)}$ ", then in this case the zeros of denominator $x=2, x=3$ are the break points of the function, or points where the function is undefined. In this case they are called (Polstelle).

While getting ready for the exams and studying at German universities it is necessary to take into consideration, that a lot of definition are completely different in designations. So, for example, the theme: "Derivative and its application" is very popular and there are a lot different examples for this topic. But the difference in definitions can produce a lot of problems and misunderstanding by solving the problem. Let's show this while doing some tasks. 
For example, one of the exercises of this chapter is: "Find a derivative of given function with x-method". In this case the main difficulty is the question itself. What is it the "x-method"? But it is only the processes to find a derivative according to its main definition. Finden die Ableitung $f^{\prime}\left(x_{0}\right)$ der Funktion $f(x)$ an der Stelle $x_{0}=3$ mit Hilfe der $h$-Methode

$$
f^{\prime}\left(x_{0}\right)=\frac{f\left(x_{0}+h\right)-f\left(x_{0}\right)}{h} .
$$

If the young people want to study at German universities, they should get prepared additionally for this, because there are not only a lot a difficulties and mismatches of translation or interpretations of some concepts and methods but there are a lot of themes and chapters in mathematics, which are not studied in schools of Ukraine. For example, the iterative numerical method for finding the roots of given function (zeros of function), which is known as Newton method (or tangent method) isn't studied within the curriculum of school math in Ukraine, moreover, this method isn't studied in every course of university math, but it is presented in the gymnasium courses of Germany. There is such an example:

Bestimme mit Hilfe des Newton-Verfahrens eine Nullstelle der Funktion

$f(x)=\frac{1}{4} x^{4}-\frac{1}{3} x^{3}-\frac{1}{2}$ auf 2 Nachkommastelen genau. Startwert $x_{0}=-1$.

For

solution it is necessary to use the formula:

$$
x_{1}=x_{0}-\frac{f\left(x_{0}\right)}{f^{\prime}\left(x_{0}\right)}
$$

Of course, the gymnasium is a kind of school and a number of topics in the gymnasium are not opened in full volume, and sometimes only some of their elements are included in exams, but nevertheless, it is necessary to be well prepared for further successful adaptation in the new educational environment.

In this way it should also be noted that the 10-13 years of school education are aimed specifically at preparing for university studies and their themes continue to be studied within the university courses such as "Mathematical Analysis", "Vector Algebra", "Analytical Geometry", "Probability Theory". These chapters of math are studied more detailed. The chapters which have not such important "university orientation", on the contrary, studied in a more simplified and shortened form.

So, the considerable attention is paid in the chapter "Geometry" to vectors and actions with them. This course in Ukrainian schools is limited to linear operations with vectors in algebraic and geometric forms, and calculating the scalar product of two vectors. German gymnasium offers the complete course, which is called "Kurse für 
Analytische Geometrie" which includes the subcourse "Vectors and lines" ("Kurse für Vektoren und Geraden") (Griesel, 2019; Gundlach, 2019; Postel, 2019; Suhr, 2019).

The pupils study in details scalar and vector products, learn formulas for finding the area of triangle and parallelogram through the module of a vector product. In addition, however, the fact that the concept of a mixed product of vectors is not introduced, students are able to find the volume of a pyramid through the ready formula of the mixed product. Sometimes the courses have a lot of differences. So, in chapter of geometry which is devoted to vectors, pupils from Ukraine have a habit to write their (vectors) coordinates as row matrix $\vec{a}=\left(a_{x} ; a_{y} ; a_{z}\right)$, but German math books give their as a column matrix $\bar{X}=\left(\begin{array}{l}x_{1} \\ x_{2} \\ x_{3}\end{array}\right)$, and it is very often confusing.

Considering that many operations with vectors are not possible without knowledge of operations with matrices, it is also given a set of certain knowledge of matrix calculus in senior school. The pupils know the types of matrices, they can find the matrix elements, they can add, multiply matrices, find the inverse matrix. Moreover, there are a number of tasks for finding the eigenvalues and eigenvectors of matrices. As an example we can show the task, where it is necessary for students to find eigenvalues for a third-order square matrix (Mathematics Exercises for high school, 2018).

Berechne die Eigehwerte der Matrix $A=\left(\begin{array}{lll}-3 & 4 & -2 \\ -6 & 7 & -3 \\ -6 & 6 & -2\end{array}\right)$.

There are a few kinds of such tasks, but they exist. Special attention should be paid to the course of analytical geometry. There is no such course at all in school mathematics in Ukraine. Ukrainian students know only two types of lines: the general equation of the line $a x+b y+c=0$ and the equation of the line with an angular coefficient $y=k x+b$.

The plane exists only conceptually, and the equation of the plane is not given at all, and if we speak about some chapters like "The plane and the straight line in space" they are the themes of Ukrainian universities only. If we speak about the content of this course, there are some real differences among definitions.

It is known that a straight line and the plane have a several types of notation, and in German schools it is preferable to write the equation (both for straight line on the plane and in space) in the parametric form. For better understanding, we will show this 
with some task. It is necessary to determine which of the points lies on a given plane. Welcher der Punkte liegt auf der Geraden $X=\left(\begin{array}{c}-1 \\ 0 \\ 1\end{array}\right)+\lambda\left(\begin{array}{c}18 \\ -3 \\ -6\end{array}\right)$

It is given some variants of answer:

\section{Antwortmöglichkeiten}
1) $P(5 ;-1 ; 3)$;
2) $P(17 ; 2 ;-3)$;
3) $S(11 ;-2 ;-3)$.

Due to the unusual recording, many students, who know this topic, have some difficulties with solving this problem. We show the scheme of its solution. So, in this case, the line is written in the parametric form:

$$
X=\left(\begin{array}{c}
x_{0} \\
y_{0} \\
z_{0}
\end{array}\right)+\lambda\left(\begin{array}{c}
m \\
p \\
s
\end{array}\right)
$$

For a Ukrainian student (this material studied in Ukraine in the first year of universities) the following form of a line equation recording is more usual:

$$
\left\{\begin{array}{l}
x=x_{0}+\lambda m \\
y=y_{0}+\lambda p \\
z=z_{0}+\lambda s
\end{array}\right.
$$

Further, Ukrainian students must remember that the parametric equation of straight line in the space can be derived from the canonical equation:

$$
\frac{x-x_{0}}{m}=\frac{y-y_{0}}{p}=\frac{z-z_{0}}{s}=\lambda .
$$

Let's show that the point $\mathrm{S}$ is the answer to this exercise. Based on the condition on task, we have:

$$
\begin{gathered}
X=\left(\begin{array}{c}
-1 \\
0 \\
1
\end{array}\right)+\lambda\left(\begin{array}{c}
18 \\
-3 \\
-6
\end{array}\right) . \\
\frac{-1-x_{0}}{18}=\frac{0-y_{0}}{-3}=\frac{1-z_{0}}{-6}=\lambda .
\end{gathered}
$$

Replace the S-point coordinates $S(11 ;-2 ;-3)$ into line equation. Get: $\frac{-1-11}{18}=\frac{0+2}{-3}=\frac{1+3}{-6}=\lambda$. From this equality we get, that value of $\lambda$ is always the same and equals $\lambda=\frac{2}{3}$. So, the point $S$ is the point, which belongs to the given straight line. So, we can note that there are a lot such kind of tasks, sometimes they are large enough and difficult, and include many steps of their solutions. 
The chapter "Linear algebra and analytic geometry" occupies an important part in math course in German school system. And here are a lot of differences, too. So, in most cases the plane equation is also given in the parametric form (Ebenengleichung in Parameterform) and it has the following describing:

$$
X=\left(\begin{array}{l}
1 \\
3 \\
4
\end{array}\right)+\lambda\left(\begin{array}{c}
1 \\
2 \\
-3
\end{array}\right)+\mu\left(\begin{array}{c}
-4 \\
1 \\
1
\end{array}\right)
$$

For example, in Ukraine such kind of the plane equation: $A x+B y+C z+D=0$ is known as the plane equation in general form, but in German course of math the same type of equation is known as the plane equation in normal form (Ebenengleichung in Normalenform). Note, that in Ukrainian universities the plane equation in the normal form is completely different kind of equation.

It should be also noted that more attention is given to the probability theory and mathematical statistics in German schools in comparison with Ukrainian schools. And the exercises are different by types, too. There are a lot of tasks and exercises with sets (Venn diagrams), and lots of questions for building trees of events, tasks where probabilities are given in the form of tables. It is possible to say that in this chapter ("The Probability Theory and Math Statistic") the great importance is given not only to solving some math problems, but also to the ability to distinguish types of events: dependent, independent, exclusive, and carry out the operations with sets. Thus, this chapter of math consists of a number of tasks; the main item of them is to understand the meaning of probability theory.

Let's show some examples. According to the data from table with events, which is below it is necessary to determine: The events $S$ and $Q$ are stochastic dependent or not.

\begin{tabular}{|l|l|l|l|}
\hline & \multicolumn{1}{|c|}{$S$} & $\bar{S}$ & \\
\hline$Q$ & 0,245 & 0,455 & 0,7 \\
\hline $\bar{Q}$ & 0,105 & 0,195 & 0,3 \\
\hline & 0,35 & 0,65 & 1 \\
\hline
\end{tabular}

Firstly, explain which kind of data we have in this table. As it is obvious there is the sum of the opposite events in the last column and in the bottom row:

$$
P(Q)+P(\bar{Q})=1 \text { и } P(S)+P(\bar{S})=1 .
$$

The probability of their joint occurrence (both of events happen at the same time) locates at the intersection of rows and columns. For example, $P(S \cdot Q)=0,245-$ is the probability, that both events $\mathrm{S}$ and $\mathrm{Q}$ occurred at the same time together. 
The solution of this task is quite easy if we understand the structure of task. So, we will find the next probabilities: $P(S \cdot Q)=0,245$ and $P(S) P(Q)=0,35 \cdot 0,7=0,245$

Let's pay attention to the construction of Abitur exam. The structure of this exam is fundamentally different from the independent exams (ZNO), which usually are taken by Ukrainian students, if they want to continue their education at the university. And it is necessary to note, that most of them (Ukrainian students) do not pass this exam (Abitur) than pass. (Government Institute for School Quality and Education Research, Munich, Abitur exam in Mathematics, 2019).

So, ZNO in math is divided into three main parts. Two first parts cover the entire course of school math, and they can contain rather easy tasks of not so high level of knowledge (for example, some exercises from forms 5-7).

The Abitur exam has two parts (workbook A and workbook B), and they haven't any tests, and there is no possibility to guess answer. Each part (workbooks A and B) has three components, there are (they are called) analysis, stochastic, geometry. The difference is that the tasks from workbook A are quite easy, and each pupil get only 90 min. for their solution, but in this situation it is strictly prohibited to use anything. In the workbook B the tasks for their structure are the same as in the workbook A (analysis, stochastic and geometry), but they are more difficult. In this way it is allowed to use some help: a calculator, statistical tables, etc.

The main target of Abitur exam is to estimate and determine the level of knowledge of applicants who want to get a university education in the future, therefore the German Ministry of Education doesn't consider the possibility to include tasks of the $5-7^{\text {th }}$ form level, where the pupil should demonstrate their ability to reduce the fraction. The exam questions are based only on the knowledge of the gymnasium level (forms 10-13), and having only ordinary professional school education, passing it is completely not possible.

The structure of exam for inside content is the next: The part "Analysis" (workbook A) contains as rule, graph of function, that should be fully analyzed using differential calculus methods (For example, the function $y=\frac{e^{2 x}}{x}$ was proposed in 2019, Abitur in Mathematics, Bavaria, Germany). In addition, in this section, it is proposed to solve several more practical (textual) problems using differential calculus methods for finding the minimum or maximum of given function.

Workbook B ( part "Analysis") contains similar tasks by structure, but they are more complicated and extensive (for example, make the analysis of functions $y=4 \ln (x+1)+\frac{4}{x+1}$ und $y=\frac{3 e^{2 x}}{e^{2 x}+1}-1,5,2019$, Bavaria). 
"Stochastic" contains questions on probability theory. In a workbook A, as a rule, they are tasks for sets and calculation of simple probabilities. There are many tasks, where conditions are given in the form of trees, Venn diagrams and tables. Workbook B can be represented as a set of tasks of the Bernoulli scheme, tasks using correlation and regression analysis. It should be noted that all types of tasks have a strictly applied focus (they based on the data of enterprises, firms, etc.).

The third part is geometry. Workbook A, as a rule contains tasks for geometry on a plane. The range of problems can be quite different from searching the distance from point to a straight line till calculation the area of a triangle through the module of vector product two vectors. In a similar part of workbook B, the tasks are the same by structure, but as rule, there are the tasks in which students have to deal with straight line or plane in the space. It is necessary to note that the exam for structure is constructed so, that the solution of the second task is the continuation of the first task and so on.

Conclusion. The main purpose of this article was to show that there are significant differences between educational programs in different countries on the example of mathematical training of future students in Germany and Ukraine. And for successful adaptation in new environment a future applicant needs not only to have a good knowledge of the language of the chosen country to study, but it is necessary to have a good subject training.

\section{REFERENCES (TRANSLATED AND RANSLITERATED)}

1. Griesel, H., Gundlach, A., Postel, H., \& Suhr, F. (2019). High level of gymnasium. Basic und Study Course. Elements of Mathematics, Berlin, Brandenburg, 263.

2. Government Institute for School Quality and Education Research, Munich, Abitur exam in Mathematics. (2019). Retrieved from https://www.isb.bayern.de/schulartspezifisches/leistungserhebungen/abiturpruefunggymnasium/mathematik/2019/

3. Mathematics Exercises for high school, (2018) (11-13 years of education). Retrieved from https://www.unterricht.de/Mathematik/Oberstufe

4. Matsko, O. (2019). Where are Ukrainians going to study. Retrieved from http://www.dsnews.ua/society/na-moskvu-kuda-uezzhayut-uchitsya-ukraintsy-30012019220000

5.Topchii, N., Demidov, S., Dergay, N., Shklyar, S. (2011) Comparative characteristics of the educational systems of Ukraine and the USA. Problems and prospects of the development of education: materials of the Intern. scientific conference (pp. 203-205). Retrieved from https://moluch.ru/conf/ped/archive/17/135/

\section{ПОРІВНЯЛЬНА ХАРАКТЕРИСТИКА НАВЧАННЯ МАТЕМАТИКИ В КОЛЕДЖАХ ТА ГІМНАЗІЯХ НІМЕЧЧИНИ ТА УКРАЇНИ}

\section{Еліна Железнякова}

кандидат фізико-математичних наук, доцент кафедри вищої математики та 
E. ZHELEZNIAKOVA, T. SILICHOVA

Comparative Characteristics of Teaching Mathematics in Colleges and Gymnasiums

in Germany and Ukraine

економіко-математичних методів

Харківський національний економічний університет імені Семена Кузнеця

ORCID ID 0000-0001-6409-4761

Zheleznizkova@m.hneu.ua

\section{Тетяна Сілічова.}

кандидат педагогічних наук, доцент кафедри вищої математики та економікоматематичних методів

Харківський національний економічний університет імені Семена Кузнеця

ORCID ID 0000-0001-5003-2711

tas.20.05.72@gmail.com

Анотація. У статті розглянуті основні особливості, аспекти і проблеми із якими можуть зіткнутися вітчизняні абітурієнти при навчанні у вищих навчальних закладах Німеччини. Основний акцент зроблений на тому, що крім труднощів психо-соціального характеру, а саме звикання до нового середовища, нового способу життя, молоді люди можуть зіткнутися 3 більш серйозними труднощами: розбіжністю рівня професійної підготовки. Відзначено і виділено основні відмінності не тільки в освітніх системах в цілому, але й в методиках викладання окремих предметів на прикладі навчання математики. Основний акцент $\epsilon$ зробленим на ті теми, які висвітлюються у старших гімназійних класах, і $є$ темами вступних іспитів в університети Німеччини. Проведений аналіз дає можливість авторам стверджувати, що підготовка до навчання за кордоном є складним процесом, що вимагає ретельної освітньої та професійної підготовки.

Ключові слова: вищий навчальний заклад; математика; навчання; проблеми адаптації; професійне навчання; іспит.

\section{СПИСОК ВИКОРИТАНИХ ДЖЕРЕЛ}

1. Griesel, H., Gundlach, A., Postel, H., \& Suhr, F. (2019). High level of gymnasium. Basic und Study Course. Elements of Mathematics, Berlin, Brandenburg, 263.

2. Government Institute for School Quality and Education Research, Munich, Abitur exam in Mathematics. (2019). Retrieved from https://www.isb.bayern.de/schulartspezifisches/leistungserhebungen/abiturpruefunggymnasium/mathematik/2019/

3. Mathematics Exercises for high school, (2018) (11-13 years of education). Retrieved from https://www.unterricht.de/Mathematik/Oberstufe

4. Matsko, O. (2019). Where are Ukrainians going to study. Куда уезжсают учиться украинцьь. Взято $3 \mathrm{http} / / / \mathrm{www} . d s n e w s . u a / s o c i e t y / n a-m o s k v u-k u d a-u e z z h a y u t-u c h i t s y a-u k r a i n t s y-$ 30012019220000

5. Topchiy, N., Demidov, S., Dergay, N., i Shklyar, S. (2011). Comparative characteristics of the educational systems of Ukraine and the USA. Сравнительная характеристика систем образования Украины и США. Problems and prospects of the development of education: materials of the Intern. scientific conference (c. 203-205). Взято 3 https://moluch.ru/conf/ped/archive/17/135/

Матеріали надійшли до редакції 01.04.2020 p.

Професіоналізм педагога: теоретичні й методичні аспекти. - Вип. 12. - Слов’янськ, 2020. 